\title{
Heavy metal index and geographical information system (GIS) approach to study heavy metal contamination: a case study of north Chennai groundwater
}

\author{
S. R. Mahapatra ${ }^{1} \cdot$ T. Venugopal ${ }^{2}$ A. Shanmugasundaram ${ }^{1} \cdot$ L. Giridharan ${ }^{3} \cdot$ M. Jayaprakash ${ }^{1}$
}

Received: 26 June 2018 / Accepted: 22 October 2020 / Published online: 11 November 2020

(c) The Author(s) 2020

\begin{abstract}
Fifty-four groundwater samples were collected from the highly industrialized area of north Chennai. These groundwater samples were tested for $\mathrm{Fe}, \mathrm{Mn}, \mathrm{Cu}, \mathrm{Ni}, \mathrm{Pb}, \mathrm{Zn}$ and $\mathrm{Cr}$ in pre-monsoon and post-monsoon periods of 2015-2016. Most of the samples in the area were found to have high concentration of heavy metals. Geographical information system was used to develop contour maps for the analysis of heavy metals, and it has been found that most of the Ambattur area was affected by the heavy metals in both the seasons. ANOVA tests were carried out on the hydro-chemical data for both the monsoon periods, and it was found that there was a common source of origin for most of the heavy metals, which was also confirmed by the correlation and principal component analysis. $T$-test indicates that there was a common source of origin of heavy metals in the study area, viz. industrial and domestic pollutants, that were found to be the main source of heavy metals in both the monsoon periods. Principal component analysis gave three important factors (principal components) for both the seasons. Pre-monsoon groundwater samples showed a common cause of origin of heavy metals than the post-monsoon samples. Heavy metal pollution index indicates that almost all the samples were not fit for drinking purpose in both the monsoon periods and metal index also indicates the non-usability of the water for drinking purpose.
\end{abstract}

Keywords Groundwater · Heavy metal index · GIS · Multivariate statistical analysis

\section{Introduction}

Groundwater is one of the most important resources for the conservation of biodiversity and to nourish the ecosystem. Overpopulation, mining activities and industrial activities have caused degradation of groundwater all over the world (Sharma et al. 2017). Developing countries have been affected by the depletion and contamination of groundwater (Ravindra et al. 2019); over-dumping of industrial and domestic wastes near the water bodies and open dump yards has been common in the developing countries (Ravindra and Mor 2019). Though the domestic wastes were considered

T. Venugopal

venupaper@gmail.com

1 Department of Applied Geology, University of Madras, Guindy, Chennai, India

2 Department of Chemistry, Government College of Engineering, Salem, Tamil Nadu, India

3 Department of Geology and mining, Gunidy, Chennai, India free from the contamination of heavy metals, ironically in recent years, increasing the usage of electronic products and the disposal of domestic e-wastes was a matter of serious concern in the developing countries, especially the waste batteries in the domestic wastes have made the scenario entirely different. With increasing dumping of both industrial and domestic wastes near the water bodies (Mor et al. 2018), heavy metals find their way into groundwater due to corrosion and dissolution. Heavy metals in groundwater can easily enter the food cycle and can cause variety of disorder problems in human being (Govil and Krishna 2018; Rahfeld et al. 2018; Muhammad et al. 2011; Tamasi and Cini 2004). Many researches in recent times have focused heavy metal pollution in the groundwater. New indices are developed to study the usefulness of water for drinking purposes. Heavy metal pollution index (HPI) was one of the common indexes, which was developed by Mohan et al., by using the desirable and maximum permissible limit of the heavy metal permitted by WHO or BIS. This index classifies the water taking into account their relative amount that was allowed in the water. Some elements were toxic in lower concentration, 
and these heavy metals were given higher priority in the index and water has been classified taking the sum of all the contribution from each heavy metal (Rahfeld et al. 2018; Muhammad et al. 2011; Abou Zakhem and Hafez 2014; Bhardwaj et al. 2017; Chaturvedi et al. 2018; Prasad et al. 2013; Prasad and Sangita 2008; Prasad and Jaiprakas 1999; Singh and Kamal 2016; Tiwari et al. 2015, 2016; Rakotondrabe et al. 2017). Metal index (MI), another index, classifies the water based on only the maximum allowed concentration of the heavy metal in the water (Tamasi and Cini 2004; Balakrishnan 2016).

In this study, highly polluted area of north Chennai was chosen, and the groundwater was tested for the heavy metal. North Chennai has a dense population and cluster of industries. The area has high concentration of small-scale industries, especially in the Ambattur industrial estate. Seven heavy metals were tested in the groundwater, which includes $\mathrm{Fe}, \mathrm{Mn}, \mathrm{Cu}, \mathrm{Ni}, \mathrm{Pb}, \mathrm{Zn}$ and $\mathrm{Cr}$. In this research, these heavy metals were subjected to principal component analysis, ANOVA and $t$-test to find out the common cause of their origin. Calculation of heavy metal pollution index and metal index was carried out to evaluate the suitability of water for drinking purpose.

\section{Study area}

The detailed sampling locations of sampling site are shown in Fig. 1a-c. The region lies between $80^{\circ} 03^{\prime}$ and $80^{\circ} 17^{\prime} \mathrm{E}$ longitudes and $13^{\circ} 03^{\prime}$ and $13^{\circ} 16^{\prime} \mathrm{N}$ latitudes. The total aerial extent is about $358.08 \mathrm{~km}^{2}$. The exact boundary was drawn by processing DEM (digital elevation model) with the Geo-Hydro tool of ArcGIS 10.3 software for watershed delineation.

The study area experiences hot climate during summer, and in the remaining period, the weather is moderate to cool. The maximum temperature differs from 37 to $44{ }^{\circ} \mathrm{C}$, while the minimum temperature varies from 18 to $27^{\circ} \mathrm{C}$. During the month of May, the temperature will be very high, soaring up to $44{ }^{\circ} \mathrm{C}$. The mean minimum temperature rarely falls below $20^{\circ} \mathrm{C}$, while the maximum temperature seldom crosses $44{ }^{\circ} \mathrm{C}$. The relative humidity in the study area varies from 60 to $85 \%$.

The chief climatic feature is that the region receives the major rainfall from the north-east (NE) monsoon, particularly from October to December. The normal annual rainfall of the district is $1152.8 \mathrm{~mm}$. Heavy rains and cyclonic storms are not strangers to Chennai. The city has experienced particularly heavy rains about once in every 10 years-1969, 1976, 1985, 1996, 1998, 2005, 2015. During December 2015, Chennai received around 490-mm rainfall, which was the highest in 100 years. The study area contains 49 water bodies that are small, medium and large in size (Fig. 1b). Out of these, seven major lakes were selected: Korattur, Ambattur, Avadi, Puzhal, Retteri, Cholavaram and Vilinjiyambakkam lakes. Several medium-to-small tanks are located in the area, but all of them are almost used as waste disposal sites. Earlier, the depths of these lakes are used to be about $4 \mathrm{~m}$, but now it is about $1.5 \mathrm{~m}$ or less.

The identification of geomorphologic features is very important for groundwater studies as shown in Fig. 1c. The maximum elevation of the study area is about $10 \mathrm{~m}$ in the west; it is around the mean sea level (MSL) in the east. Thus, the area gently slopes towards east. There is no remarkable elevation difference in the north-south direction, except for the two river courses. Important geomorphic units include the anthropogenic terrain of anthropogenic origin, shallow/ deep pediment and pediplain of denudational origin, and the older deltaic plain of coastal and fluvial origin. Most of the area consists of alluvial plains, especially between the Koratalai and Cooum rivers. The detailed geomorphology map is shown in Fig. 1c.

Geologically, the study area is underlain by formations ranging in age from Archean to Recent. Gneiss and pyroxene granulite rocks of Proterozoic Era occur as basement at depths between 65 and $105 \mathrm{~m}$ (16). These rocks are overlain by the Gondwana Formation consisting of clay, shale, sandstone, conglomerate and boulders. Tertiary formations comprising clays, shale and sandstone overlay these. The Quaternary-Recent alluvium consisting of clay, silt, sand, gravel and pebbles occurs at the top, with thickness varying from 45 to $60 \mathrm{~m}$; the thickness is higher between the rivers and increases towards the coast. The geology map of the study area (Fig. 1c) illustrates that almost the entire central part of the study area is comprised of laterite rock with small patches of sandstone.

\section{Materials and methods}

The methodology adopted in an analysis decides the precision and accuracy of the analytical results. Analysis depends critically on the acquisition of a sample that is truly representative of the material to be analysed. Groundwater samples were collected during June 2015 (pre-monsoon) and January 2016 (post-monsoon) as the NE monsoon is active from mid-October to mid-December; morphological studies were carried out during 2015-2016. A stratified random sampling design was chosen, and 54 groundwater samples of both seasons were sampled to provide sufficient coverage of the study area. The sample containers were made from high-density polyethylene. The containers were pre-cleaned by soaking them in $2 \mathrm{~mol} \mathrm{~L}^{-1} \mathrm{HNO}_{3}$ for $24 \mathrm{~h}$ and washed 3-4 times with de-ionized water. Before collecting the samples, the containers were rinsed with the samples. The water samples were collected from the wells at $10 \mathrm{~cm}$ below 

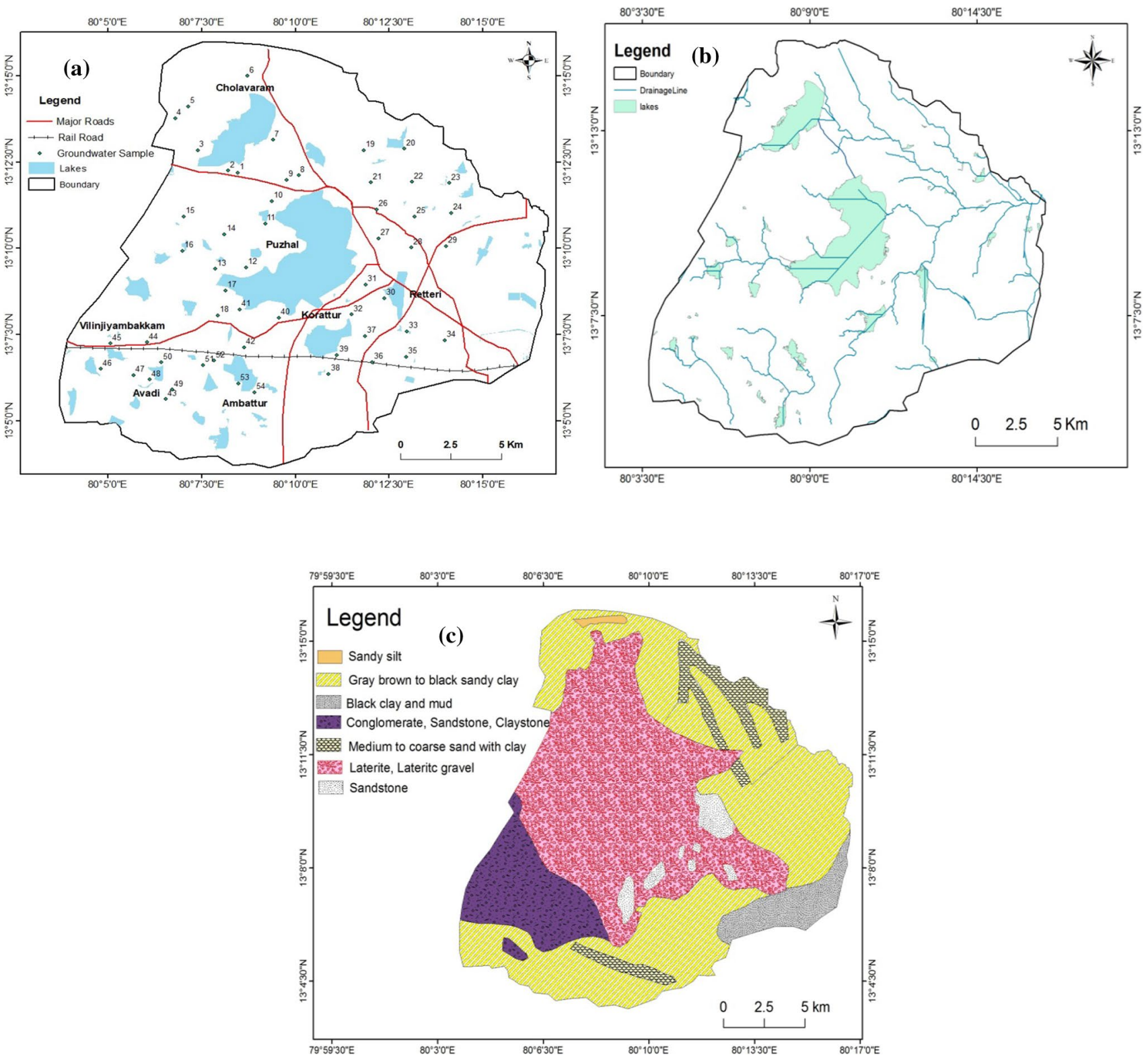

Fig. 1 a-c Base map of the study area showing the sampling station for both the monsoons, drainage map of the study area depicting the water bodies and the geological map of the study area showing various rock types

the static water level using a water sampler. Groundwater samples were collected from tube wells and borewells after duration of $5 \mathrm{~min}$ to avoid stock water from the pipe. The trace metal concentrations were determined by flame AAS (AAnalyst 700 Perkin Elmer) after calibration with standard solutions (MERCK). Before running the sample analysis, the instrument was checked with the standard reference material (SLRS Riverine Water, National Research Council, Canada).

Water quality index (WQI) was used to evaluate the suitability of water for drinking and irrigation (Pant et al. 2018; Sadat-Noori et al. 2013; Das Kangabam et al. 2017; Gautam et al. 2018; Krishna kumar et al. 2014; Saleem et al. 2016).
But the effect of trace metals/heavy metals was not taken into account in WQI calculation. Heavy metal pollution index (HPI) was used to find the suitability of the use of water for the drinking purpose, which takes into account the concentration of the heavy metal in the groundwater. In this work, HPI (Eq. 1) was calculated by the method used by Mohan et al. (2008) and Prasad and Jaiprakas (1999).

HPI is calculated using the following equation

$\mathrm{HPI}=\frac{\sum_{i=1}^{n} W_{i} Q_{i}}{\sum_{I=1}^{n} W_{i}}$ 
where $W_{i}$ is defined as the unit weightage of a heavy metal and $Q_{i}$ is the sub-index of a heavy metal and $n$ is the number of heavy metal measured to determine HPI.

$Q_{i}$, (Eq. 2), is the sub-index which is given by the following equation.

$Q_{i}=\sum_{i=1}^{n} \frac{\left|M_{i}-I_{i}\right|}{\left(S_{i}-I_{i}\right)}$

Here, $M_{i}$ is the concentration of the $i$ th heavy metal that is measured in the particular season, $I_{i}$ is the maximum desirable value of that particular ( $i$ th) heavy metal given by WHO (2012) and $S_{i}$ is the highest permissible limit that is allowed by WHO (2012). The modulus is taken to give only the numerical difference between the maximum desirable limit and the concentration of the heavy metal present in the groundwater.

$W_{i}=\frac{1}{S_{i}}$

In this study, $W_{i}$ (Eq. 3) is taken as inverse proportional of the standard permissible value of the $i$ th heavy metal.

\section{Results and discussion}

\section{Seasonal variation of the heavy metals}

Table 1 summarizes the results of the trace metals and $\mathrm{pH}$ of the groundwater in the north Chennai region. Spatial variation of the heavy metals and ions in water was studied by many authors to describe the distribution of the contaminants in the study area (Krishna kumar et al. 2014; Venugopal et al. 2008). In this study, also spatial distribution of heavy metals was used to analyse the contaminants in the study area. The $\mathrm{pH}$ of the water is one of the important parameters, which, although does not have direct influence on the human health, can be the deciding factor in many of the physico-chemical character of the water. $\mathrm{pH}$ decides the ions present in the water, especially the metal ions that may be soluble in certain $\mathrm{pH}$ and becomes insoluble in another $\mathrm{pH}$. The pathogenic activity of the micro-organism may also be controlled by the $\mathrm{pH}$ of the water (Prasad et al. 2013). $\mathrm{pH}$ in the pre-monsoon samples varies from 5.8 to 7.7 , whereas in the post-monsoon, the variation is from 5.8 to 8.0. From Fig. $2 \mathrm{a}$ and $\mathrm{b}$, it was found that lower $\mathrm{pH}$ of water was found to be observed in the northern part of the study area for both the pre-monsoon and post-monsoon periods, especially near Cholavaram lake. The $\mathrm{pH}$ of water was found to be higher in the southern part of the study area. There was a demarcation of the study area in the basis of $\mathrm{pH}$, with lower $\mathrm{pH}$ seen in the north-eastern area during both the seasons and higher $\mathrm{pH}$ in the southern part of the study area. It can be seen in Fig. 3a and $b$ that most part of the northern study area has lower iron value in both the pre-monsoon and postmonsoon periods. Southern and eastern parts of the study area, especially near the industrialized area of Ambattur and potteri regions, have a higher concentration of the iron in the groundwater during both pre-monsoon and post-monsoon seasons. This can be due to the industrial pollution and dumping of scraps in these areas, which would have caused the infiltration of iron into the groundwater.

Manganese values for both the pre- and post-monsoon were from 0.006 to 7.130 and 0.001 to $5.063 \mathrm{mg} / \mathrm{L}$, respectively. It is observed from Fig. $4 \mathrm{a}$ and $\mathrm{b}$ that most of the sampling sites show the concentration of Mn more than the permissible limit. Manganese value in both the monsoons was found to be lower in the western part of the study area. The south-eastern part and eastern part of the study area almost showed higher value of Mn than the permissible limit during both the pre-monsoon and post-monsoon seasons. It can be inferred from Fig. $4 \mathrm{a}$ and $\mathrm{b}$ that post-monsoon samples showed a higher value of Mn concentration in most part of the study areas, and this may be attributed to the dissolution of Mn from the surface onto the groundwater during the monsoon rains.

Copper value for the pre-monsoon was found to be 0.028 to $0.395 \mathrm{mg} / \mathrm{L}$ and for the post-monsoon 0.01 to $0.419 \mathrm{mg} / \mathrm{L}$. It was found that during the pre-monsoon period, some of
Table 1 Analytical results of trace metals in the study region for both pre-monsoon and postmonsoon

\begin{tabular}{|c|c|c|c|c|c|c|c|c|c|c|}
\hline & \multicolumn{4}{|c|}{ Pre-monsoon } & \multicolumn{4}{|c|}{ Post-monsoon } & \multirow[b]{2}{*}{ WHO 2012} & \multirow[b]{2}{*}{ BIS 2012} \\
\hline & MIN & MAX & AVG & STDV & MIN & MAX & AVG & STDV & & \\
\hline $\mathrm{pH}$ & 5.8 & 7.7 & 7.0 & 0.4 & 5.8 & 8 & 7.2 & 0.5 & $7-9.2$ & $6.5-8.5$ \\
\hline $\mathrm{Fe}(\mathrm{mg} / \mathrm{L})$ & 0.102 & 6.268 & 0.630 & 0.898 & 0.019 & 8.855 & 0.546 & 1.317 & 0.300 & 0.300 \\
\hline Mn (mg/L) & 0.006 & 7.130 & 0.478 & 1.130 & 0.001 & 5.063 & 0.518 & 1.028 & 0.05 & $0.1-0.3$ \\
\hline $\mathrm{Cu}(\mathrm{mg} / \mathrm{L})$ & 0.028 & 0.395 & 0.142 & 0.070 & 0.010 & 0.419 & 0.042 & 0.057 & 0.005 & 0.05 \\
\hline $\mathrm{Ni}(\mathrm{mg} / \mathrm{L})$ & 0.014 & 0.220 & 0.082 & 0.047 & 0.000 & 0.113 & 0.025 & 0.027 & 0.02 & 0.02 \\
\hline $\mathrm{Pb}(\mathrm{mg} / \mathrm{L})$ & 0.065 & 0.423 & 0.163 & 0.059 & 0.005 & 0.337 & 0.168 & 0.080 & 0.01 & 0.01 \\
\hline $\mathrm{Zn}(\mathrm{mg} / \mathrm{L})$ & 0.001 & 1.014 & 0.048 & 0.143 & 0.002 & 0.458 & 0.062 & 0.094 & 3 & $5.0-15.0$ \\
\hline $\mathrm{Cr}(\mathrm{mg} / \mathrm{L})$ & 0.019 & 0.539 & 0.262 & 0.149 & 0.009 & 0.309 & 0.052 & 0.043 & 0.05 & 0.05 \\
\hline
\end{tabular}

要

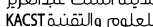



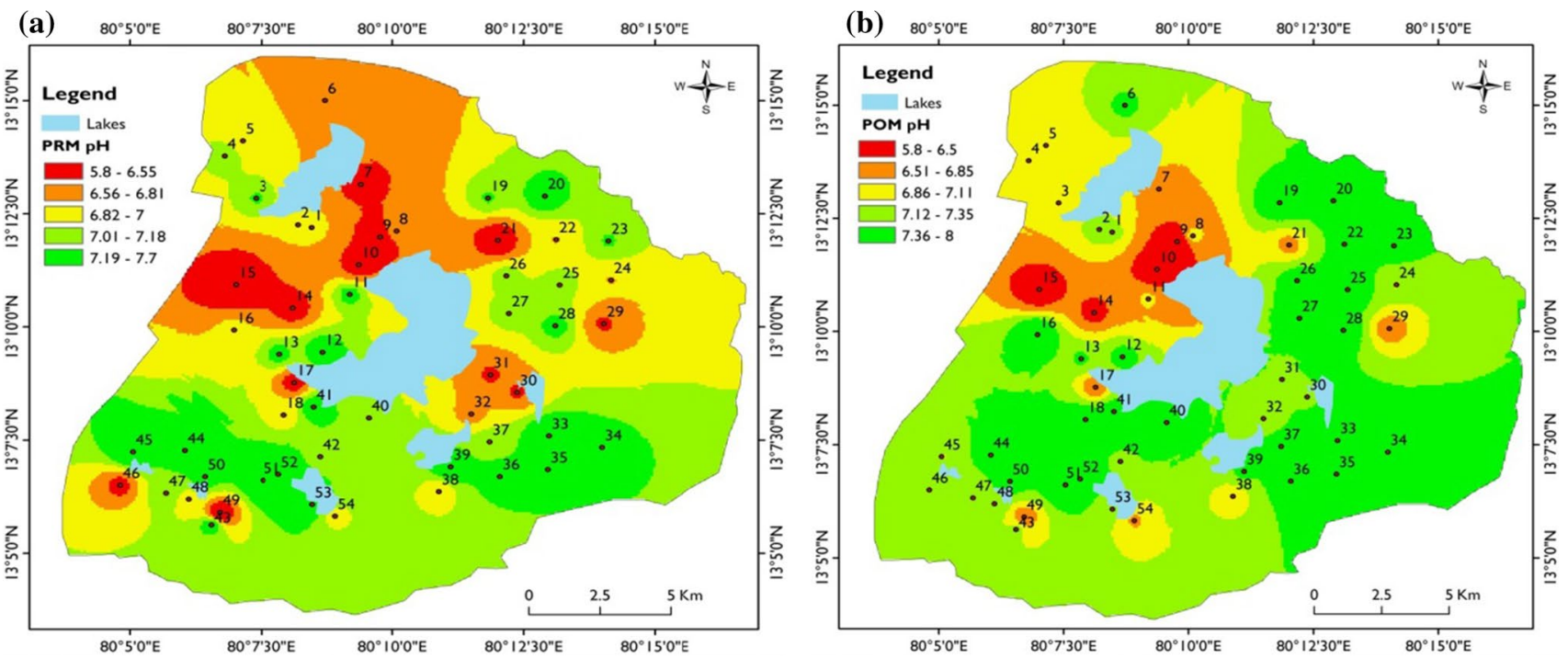

Fig. 2 a, b Spatial variation of $\mathrm{pH}$ in the groundwater for pre-monsoon and post-monsoon
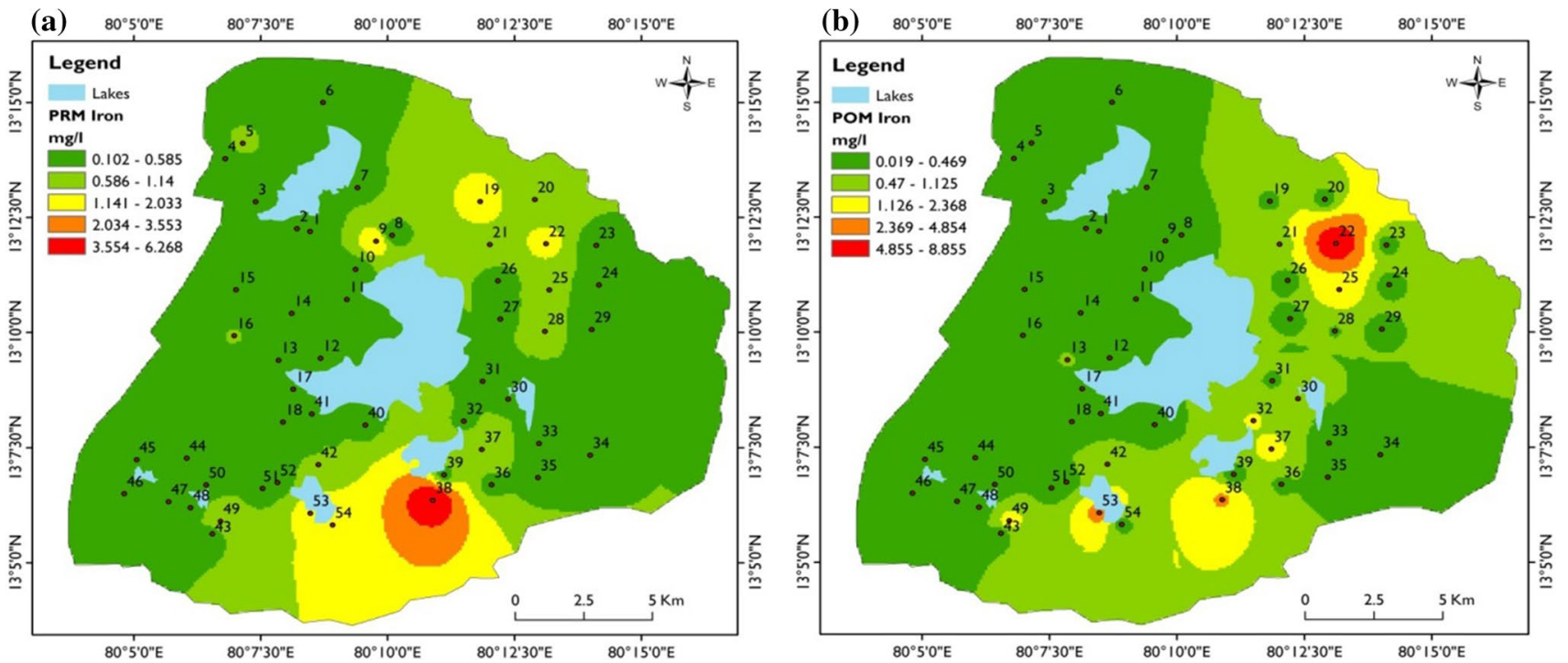

Fig. 3 a, b Spatial variation of iron in the groundwater for pre-monsoon and post-monsoon, respectively

the samples showed higher value of copper concentration than the WHO-permitted limit, and in the post-monsoon, almost all samples are found to be within the WHO permissible limit. From Fig. 5a and b, it can be inferred that post-monsoon showed lower value of copper compared to that of the pre-monsoon in almost all the sampling stations. This may be attributed to the dilution of water during the monsoon period.

Nickel value for both pre-monsoon and post-monsoon periods was found to be 0.014 to 0.220 and BDL to $0.113 \mathrm{mg} / \mathrm{L}$, respectively. From Fig. 6a and b, it can be inferred that most of the sampling sites in the north-western part of the study area were less number of industrial activities which was found to have lesser value of nickel in both the monsoons. There was a significant difference between the occurrence of nickel in the southern region in the pre-monsoon and post-monsoon. In the pre-monsoon period, southern region showed a significantly higher value of nickel concentration than in the post-monsoon. In the eastern area, post-monsoon showed a higher value of nickel compared to the pre-monsoon season. Nickel has both the dilution effect and dissolution effect in these regions; dilution effects decrease the concentration, whereas dissociation (geologically) increases the concentration.

Lead concentration was found to be higher in the entire sampling site in the study area. In the pre-monsoon, all the 

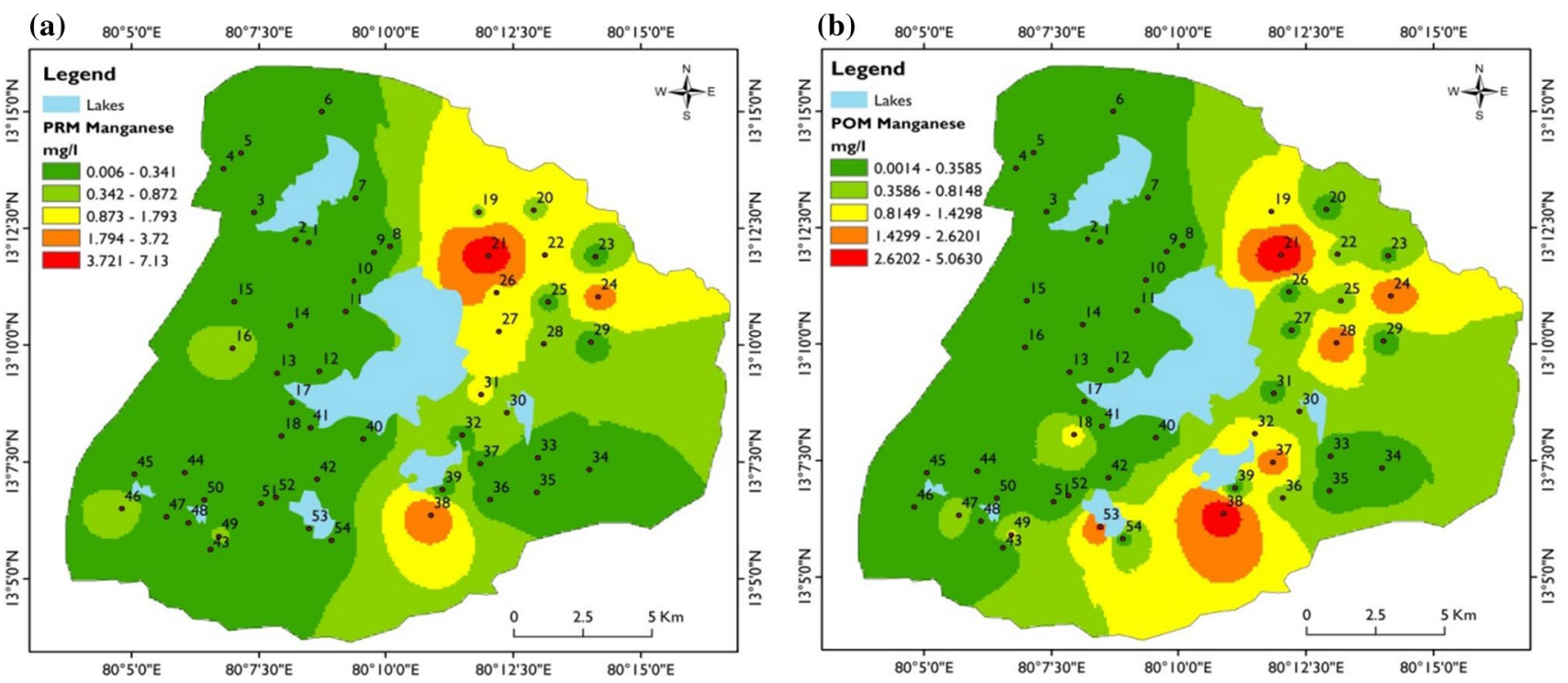

Fig. 4 a, b Spatial variation of Mn in the groundwater for pre-monsoon and post-monsoon, respectively
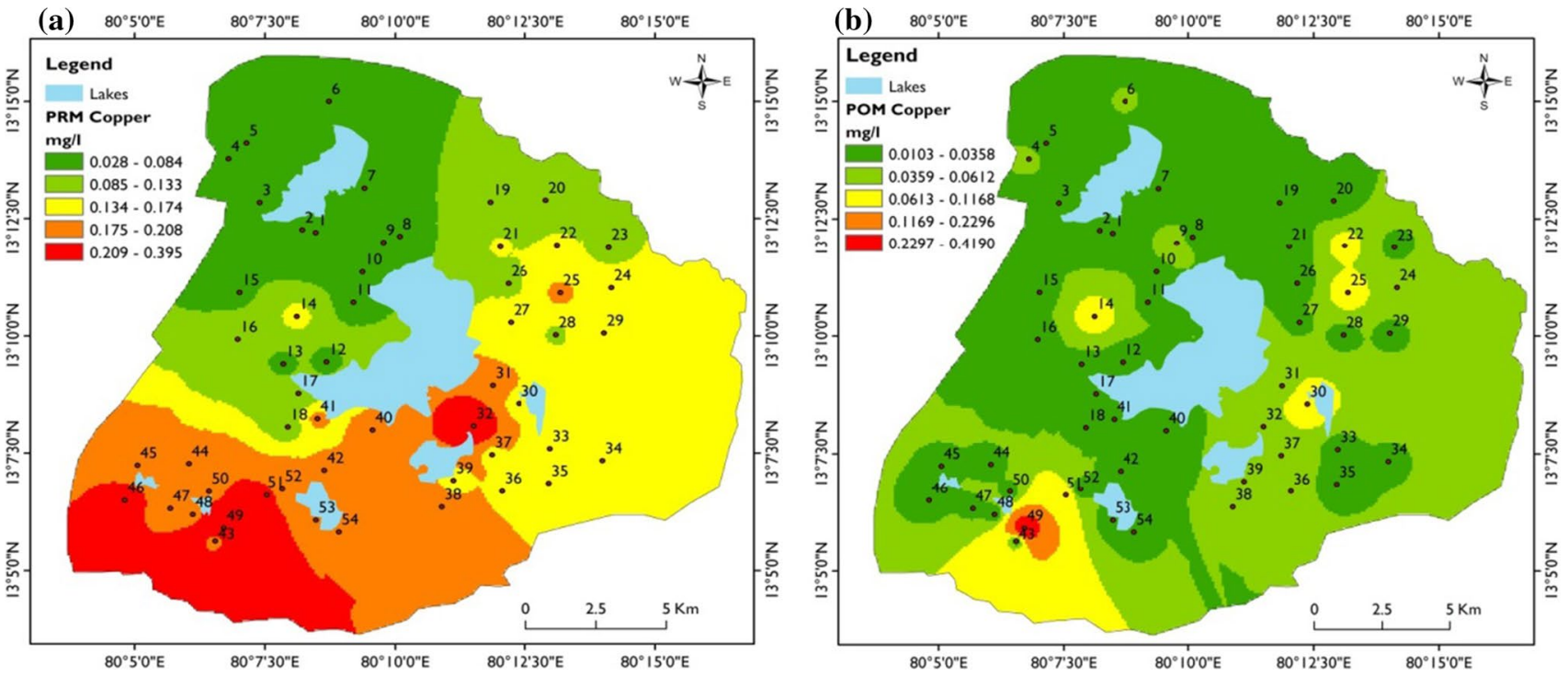

Fig. 5 a, b Spatial variation of $\mathrm{Cu}$ in the groundwater for pre-monsoon and post-monsoon, respectively

station showed lead concentration higher than the permissible limit. While in the post-monsoon except for the one sampling site all other places showed lead concentration higher than the permissible limit. The lead concentration in the premonsoon was found to be between 0.065 to $0.423 \mathrm{mg} / \mathrm{L}$ and 0.005 to $0.337 \mathrm{mg} / \mathrm{L}$ for the post-monsoon. Figure $7 \mathrm{a}$ and $b$ shows the spatial distribution of lead in the pre-monsoon and post-monsoon periods. From Fig. $7 \mathrm{a}$ and $\mathrm{b}$, it can be inferred that due to percolation of lead into the groundwater during the monsoon period, the post-monsoon showed higher concentration of lead in the northern places of the study area. The groundwater near the lakes of the Cholavaram and Puzhal had higher concentration of the lead in the post-monsoon validating the percolation theory of lead into the groundwater, i.e. dissolution of the lead from the surface and subsequent accumulation in the groundwater. These can be attributed to the higher rate of e-waste in these areas.

The concentration of zinc in the pre-monsoon period was found to be between 0.001 and $1.014 \mathrm{mg} / \mathrm{L}$ and in postmonsoon from 0.002 to 0.458 . The values of zinc in both the seasons were found to be within the permissible limit prescribed by BIS and WHO 2012. The spatial variation of the 

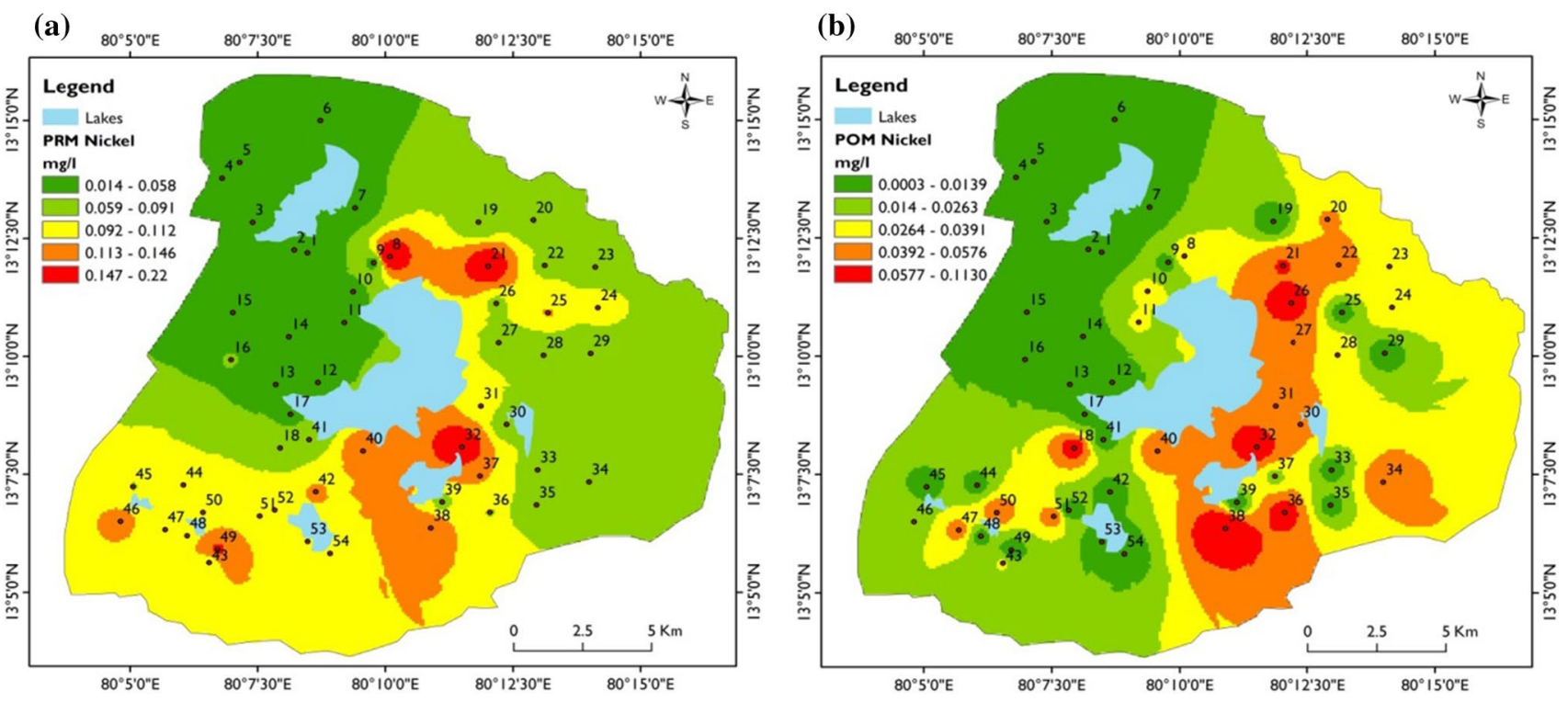

Fig. 6 a, b Spatial variation of Ni in the groundwater for pre-monsoon and post-monsoon, respectively
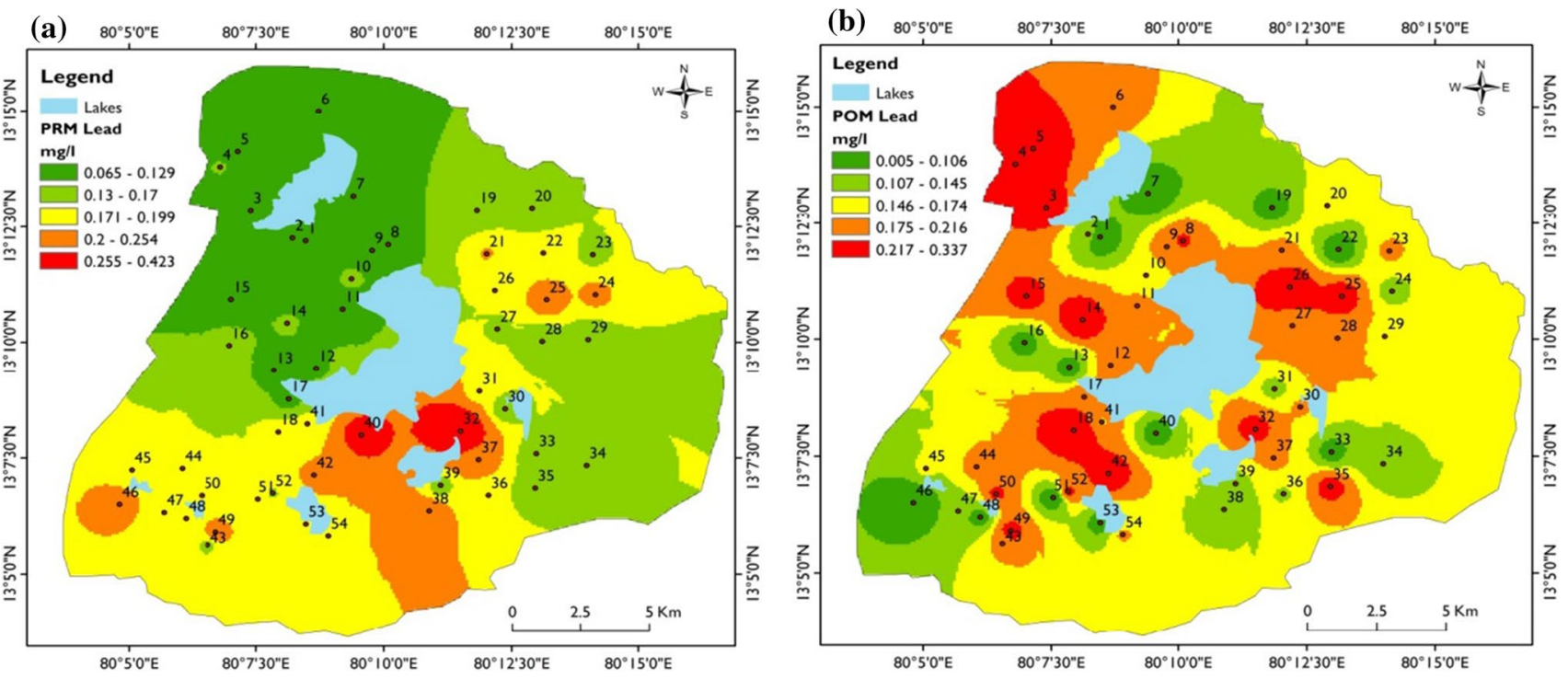

Fig. 7 a, b Spatial variation of $\mathrm{Pb}$ in the groundwater for pre-monsoon and post-monsoon, respectively

zinc in the study area is represented in Fig. 8a and b. From the figure, it can be seen that the southern part of the study area has a higher concentration of zinc in the pre-monsoon and during post-monsoon and that the eastern part of the study area shows a higher concentration of zinc compared to other regions.

Chromium concentration was found to be between 0.019 and $0.539 \mathrm{mg} / \mathrm{L}$ in the pre-monsoon and 0.009 and $0.309 \mathrm{mg} / \mathrm{L}$ in the post-monsoon periods. The seasonal variability of the chromium was more pronounced than the other trace metals as shown in Fig. 9 (a) and (b). The southern part of the study area was found to have concentration of chromium higher than the permissible level in the pre-monsoon season, while this region showed lower concentration in the post-monsoon period. During postmonsoon, north-eastern part of the study region towards the north of Puzhal lake showed a higher concentration of chromium more than the permissible limit. This region, however, showed a lower concentration in the pre-monsoon region. 
(a)

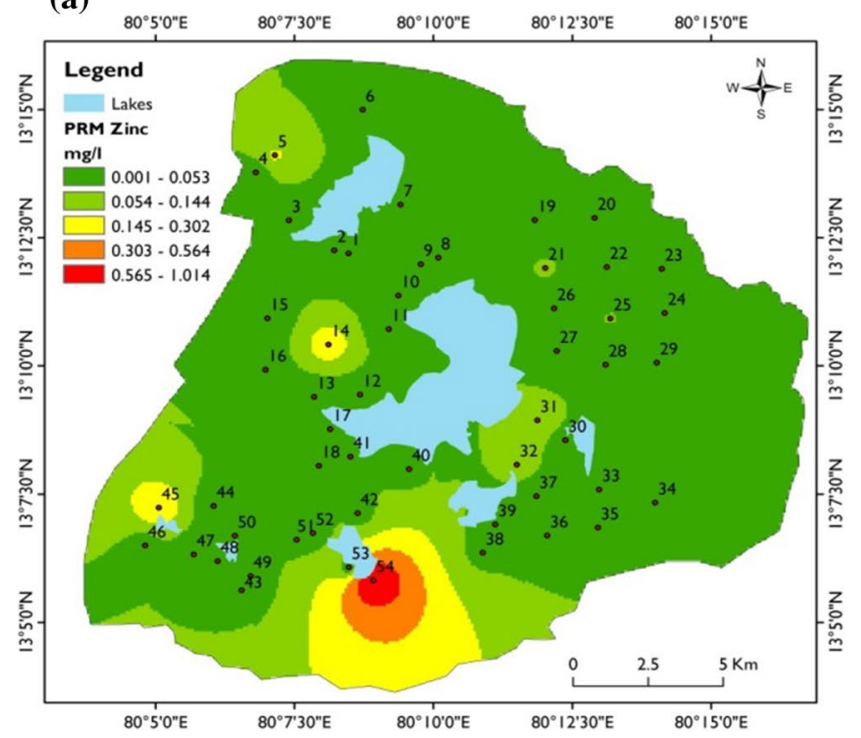

(b)

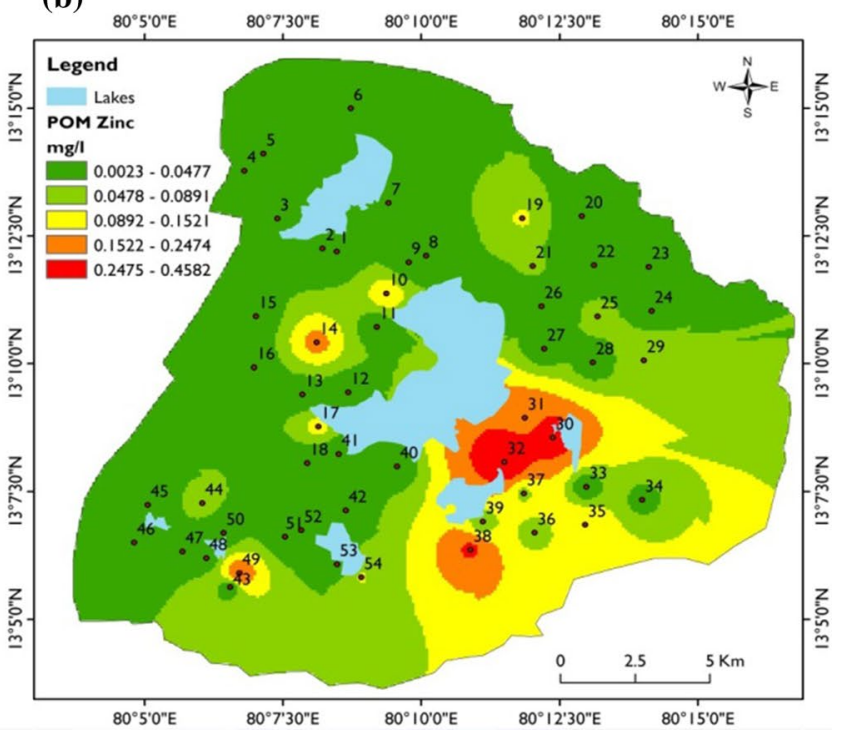

Fig. 8 a, b Spatial variation of $\mathrm{Zn}$ in the groundwater for pre-monsoon and post-monsoon, respectively
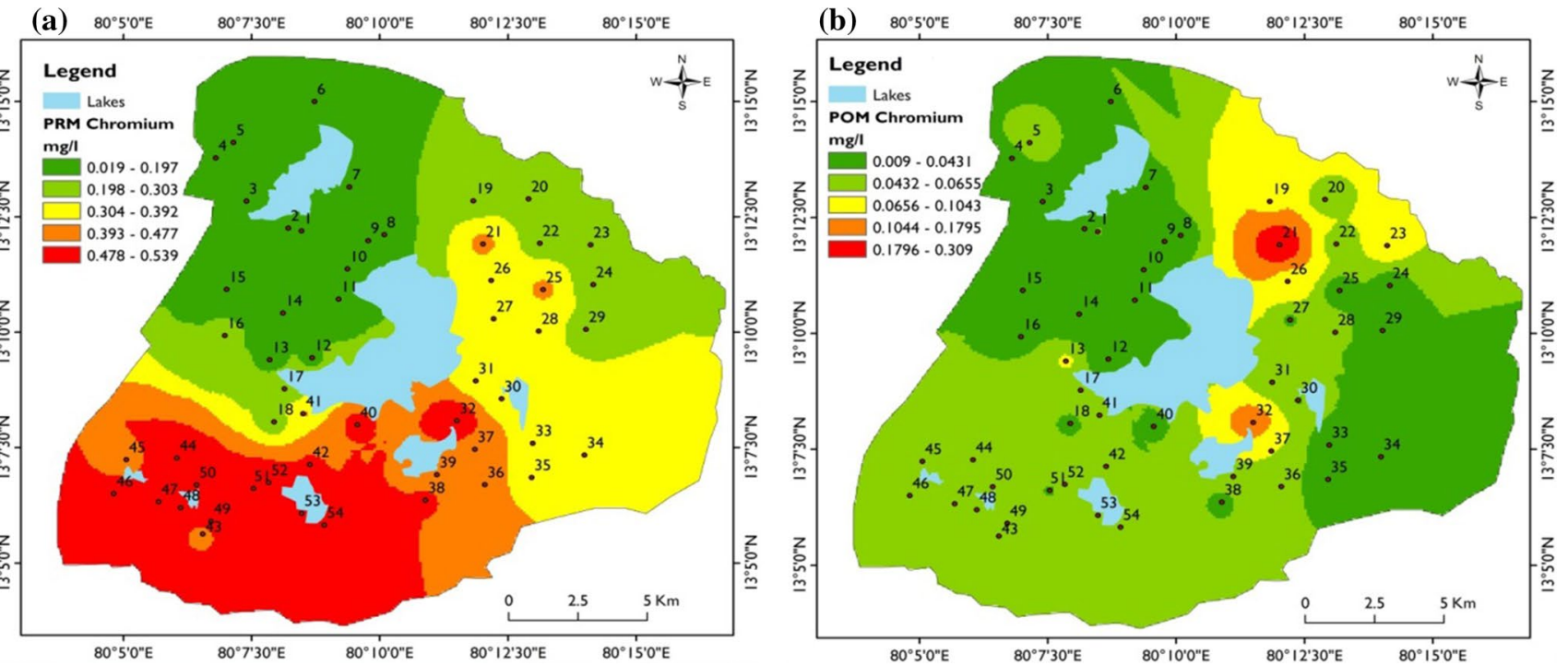

Fig. 9 a, b Spatial variation of $\mathrm{Cr}$ in the groundwater for pre-monsoon and post-monsoon, respectively

\section{ANOVA and paired $t$ test}

To find out the factor controlling the heavy metal occurrence in groundwater, ANOVA and paired $t$ test were used in this study (Muhammad et al. 2010). Trace metals in groundwater in both pre- and post-monsoon were subjected to the following null hypothesis of $t$-test to determine any significant difference in their origin.

$\mathrm{H}_{\mathrm{o}}$ : There is no significant difference in the origin of the trace metals in the pre-monsoon and post-monsoon.
The results of the $t$-test are presented in Table 2. It can be observed from Table 2 that $\mathrm{Fe}, \mathrm{Mn}, \mathrm{Pb}$ and $\mathrm{Zn}$ have $t$-test values less than the tabulated value of 2.009 at $5 \%$ level of significance. This implies that there is an acceptance of metal towards the null hypothesis, and hence, it can be concluded that the occurrence of these metals has a common source of origin during both pre-monsoon and post-monsoon periods. While trace metals $\mathrm{Cu}, \mathrm{Ni}$ and $\mathrm{Cr}$ have t-test values significantly higher than the tabulated value at 5\% level of significance, the null hypothesis was rejected. 
Table 2 Results of paired sample $t$-test of the heavy metals in pre-monsoon and post-monsoon seasons

\begin{tabular}{lllllll}
\hline Trace metal & Mean & Std. deviation & Correlation & $t$ & Df & Sig \\
\hline $\mathrm{Fe}$ & 83.52 & 1240 & 0.42 & 0.495 & 53 & 0.001 \\
$\mathrm{Mn}$ & -39.95 & 706.46 & 0.790 & 0.416 & 53 & 0.000 \\
$\mathrm{Cu}$ & 100.71 & 63.68 & 0.510 & 11.62 & 53 & 0.000 \\
$\mathrm{Ni}$ & 57.17 & 41.91 & 0.459 & 10.02 & 53 & 0.000 \\
$\mathrm{~Pb}$ & -5.15 & 99.69 & 0.001 & 0.379 & 53 & 0.996 \\
$\mathrm{Zn}$ & -13.46 & 159.95 & 0.137 & 0.619 & 53 & 0.323 \\
$\mathrm{Cr}$ & 210.01 & 141.9 & 0.314 & 10.88 & 53 & 0.021 \\
\hline
\end{tabular}

The result suggests that these metals have different origins of occurrence during the two monsoon periods. From Table 2, there is a correlation between the pre-monsoon and post-monsoon values; it can be inferred that there is no significant correlation between the pre-monsoon and post-monsoon values except for $\mathrm{Mn}$, which has a correlation value of nearly 0.80 . The results of correlation suggest that monsoon had a significant effect on the occurrence of trace metals in water. The source of origin of the trace metals can be attributed to the anthropogenic activities around the lake. The physical verification of the area revealed that there were a number of dumping sites in and round the lake area and landfills, which may lead to the infiltration of the trace metals and mixing into the groundwater.

Analysis of variance (ANOVA) of trace metals in groundwater in both pre- and post-monsoon was carried out to find whether there was a common source of origin among the trace metals found in the water. One-way ANOVA was used to compare the variability of scores for both intra-group (within the group) and inter-group (between the groups). The results of the ANOVA for inter- and intra-group are tabulated in Table 3. Hypothesis has been formulated to check whether there was a common origin of the trace metals in each monsoon.

$\mathrm{H}_{\mathrm{o}}$ : There is no significant difference in the origin of the trace metals.

\section{HPI and MI}

Water can be considered unfit for drinking when the HPI value exceeds 100 (Prasad and Sangita 2008). Tables 4 and 5 give the value of HPI for both the monsoon periods and also the mean deviation and per cent deviation from the mean value. The mean deviation and per cent deviation can be used to compare different water samples in terms of HPI index; more negative deviation indicates that the water is better compared to the other sampling sites, although it may not necessarily be considered fit for drinking. More positive deviation indicates that the water is deteriorated more than the other sampling sites making them more unsafe for the drinking purposes.
The HPI for the pre-monsoon was found to vary from 90.31 to 906.80 with an average of 399.85 , and for the postmonsoon, the variation was 31.01 to 450.22 with an average of 135.82 (Table 4 ). In both the seasons, it was found that no station has HPI falling under low class $(\mathrm{HPI}<15)$ or in the middle class (HPI $=15-30)$; all the sampling sites have a HPI value falling under high class (HPI > 30). In the pre-monsoon, only sampling site 3 showed lower value of HPI and all other sites were found to have HPI higher than 100 , which shows that the groundwater was unfit for drinking purpose. In the post-monsoon, sampling stations 1 and 7 showed HPI values lower than 50. Sampling stations 2, 12, 13, 16, 19, 29, 33, 39, 46, 48 and 54 showed HPI value between 51 and 100. All other sites showed HPI value greater than 100 (Fig. 10). It was found that sampling site 3 showed a higher value of HPI in the post-monsoon. The value of HPI shows that no site was found to be free from contamination of heavy metals in both the monsoon periods (Fig. 10). This can be particularly attributed to the excessive dumping of the waste, which could lead to the percolation of the heavy metal. Ambattur area, which was known for the industrial activity, would lead to accumulation of large amount of industrial wastes, and these wastes dumped in the nearby area and near the lake would have caused the pollution of water. In the pre-monsoon period, the concentration of the heavy metal would have been enhanced by the evaporation and reduction in water table due to the withdrawal of water, whereas in the post-monsoon, dilution of water would have taken place due to the percolation of water from the surface due to the monsoon rain. Overall, it has been found that the north Chennai area groundwater was highly contaminated with heavy metals and the level of HPI in some places was alarmingly high that necessitates series steps to be taken to control the pollution of heavy metal in the groundwater of the region.

\section{Metal index}

Metal index calculation used in this work is primarily based on the report of Tamasi and Cini (2004). Metal index (Eq. 4) is calculated using the following equation

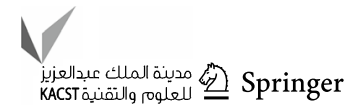




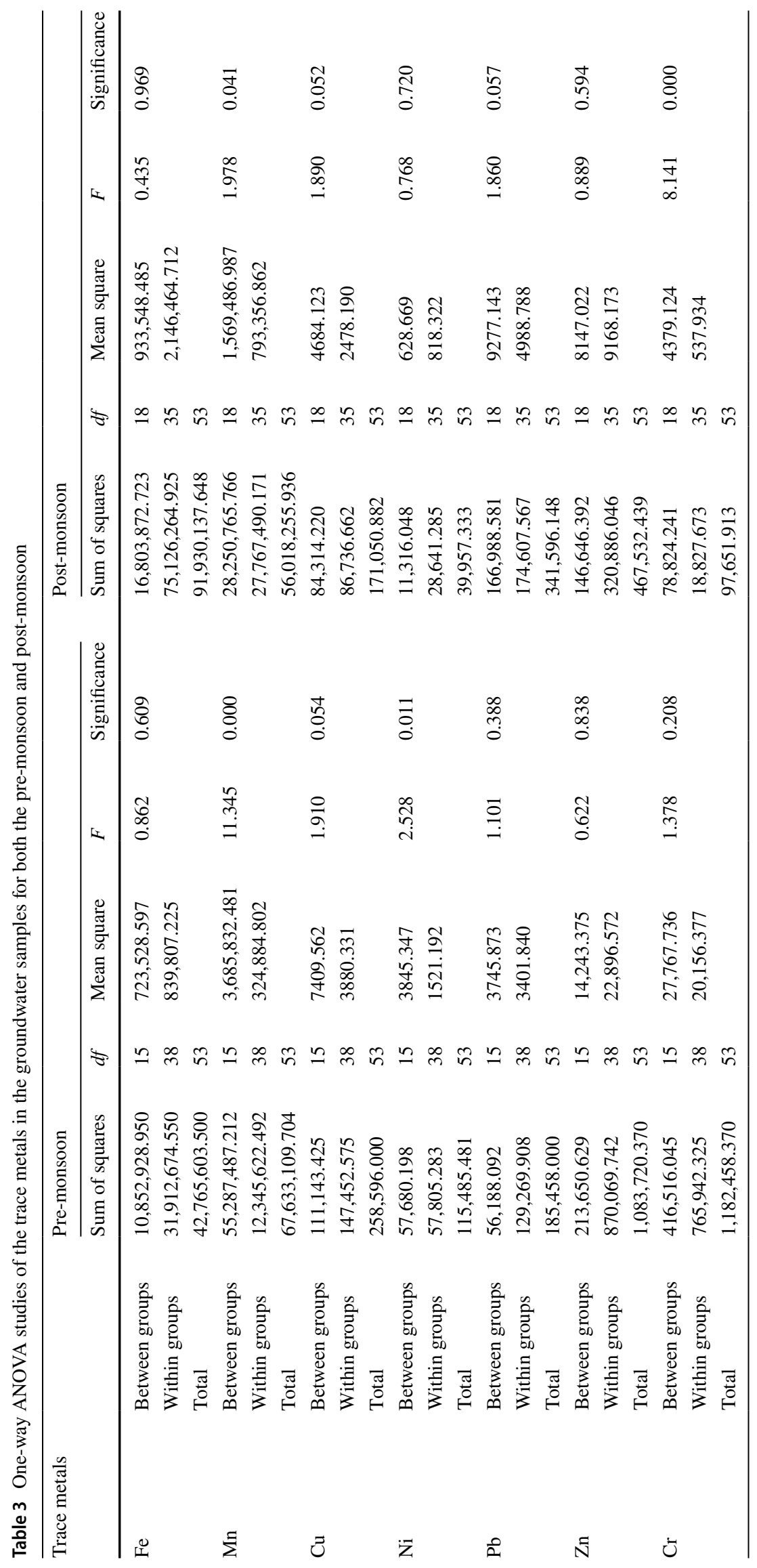


Table 4 Heavy metal pollution index and metal index in the north Chennai groundwater region during pre-monsoon and post-monsoon seasons

\begin{tabular}{|c|c|c|c|c|c|c|c|c|}
\hline Sampling site & HPI PRM & Mean deviation & $\%$ deviation & MI PRM & HPI POM & Mean deviation 2 & $\%$ deviation 3 & MI POM \\
\hline 1 & 103.91 & -259.85 & -71.43 & 3.84 & 36.17 & -129.80 & -78.21 & 1.63 \\
\hline 2 & 119.13 & -244.63 & -67.25 & 4.79 & 70.58 & -95.38 & -57.47 & 3.78 \\
\hline 3 & 90.31 & -273.44 & -75.17 & 3.57 & 130.93 & -35.04 & -21.11 & 6.51 \\
\hline 4 & 154.24 & -209.51 & -57.60 & 5.39 & 135.24 & -30.73 & -18.52 & 6.35 \\
\hline 5 & 120.03 & -243.73 & -67.00 & 4.94 & 140.12 & -25.85 & -15.57 & 6.77 \\
\hline 6 & 108.77 & -254.98 & -70.10 & 4.16 & 109.83 & -56.14 & -33.83 & 5.24 \\
\hline 7 & 135.24 & -228.51 & -62.82 & 5.00 & 31.01 & -134.96 & -81.32 & 1.56 \\
\hline 8 & 661.68 & 297.93 & 81.90 & 15.99 & 210.57 & 44.60 & 26.87 & 7.39 \\
\hline 9 & 205.40 & -158.36 & -43.53 & 8.75 & 112.89 & -53.07 & -31.98 & 5.31 \\
\hline 10 & 219.48 & -144.27 & -39.66 & 7.50 & 166.42 & 0.46 & 0.27 & 6.56 \\
\hline 11 & 170.95 & -192.80 & -53.00 & 6.36 & 154.46 & -11.51 & -6.94 & 5.66 \\
\hline 12 & 205.94 & -157.81 & -43.38 & 7.32 & 92.14 & -73.83 & -44.48 & 4.38 \\
\hline 13 & 191.31 & -172.44 & -47.41 & 7.03 & 60.52 & -105.45 & -63.53 & 3.89 \\
\hline 14 & 193.33 & -170.42 & -46.85 & 7.29 & 140.93 & -25.03 & -15.08 & 6.85 \\
\hline 15 & 195.34 & -168.41 & -46.30 & 6.76 & 149.36 & -16.61 & -10.01 & 6.39 \\
\hline 16 & 298.79 & -64.96 & -17.86 & 12.68 & 63.45 & -102.51 & -61.77 & 3.20 \\
\hline 17 & 220.68 & -143.08 & -39.33 & 7.73 & 115.10 & -50.87 & -30.65 & 5.72 \\
\hline 18 & 360.71 & -3.04 & -0.84 & 12.09 & 371.83 & 205.86 & 124.04 & 15.24 \\
\hline 19 & 316.47 & -47.29 & -13.00 & 14.31 & 83.25 & -82.72 & -49.84 & 6.44 \\
\hline 20 & 303.43 & -60.32 & -16.58 & 12.88 & 194.21 & 28.24 & 17.01 & 6.71 \\
\hline 21 & 906.80 & 543.05 & 149.29 & 46.91 & 450.22 & 284.25 & 171.27 & 30.40 \\
\hline 22 & 409.01 & 45.25 & 12.44 & 17.57 & 183.74 & 17.77 & 10.71 & 15.55 \\
\hline 23 & 335.81 & -27.95 & -7.68 & 10.99 & 187.36 & 21.39 & 12.89 & 7.74 \\
\hline 24 & 483.96 & 120.21 & 33.05 & 21.91 & 200.24 & 34.27 & 20.65 & 12.49 \\
\hline 25 & 542.74 & 178.99 & 49.21 & 18.44 & 142.21 & -23.75 & -14.31 & 9.57 \\
\hline 26 & 418.71 & 54.96 & 15.11 & 18.03 & 370.10 & 204.13 & 122.99 & 11.89 \\
\hline 27 & 420.96 & 57.20 & 15.73 & 18.57 & 219.02 & 53.05 & 31.97 & 7.80 \\
\hline 28 & 314.45 & -49.30 & -13.55 & 12.87 & 234.20 & 68.24 & 41.12 & 14.70 \\
\hline 29 & 295.72 & -68.03 & -18.70 & 10.11 & 75.14 & -90.83 & -54.73 & 3.86 \\
\hline 30 & 345.41 & -18.34 & -5.04 & 13.68 & 216.98 & 51.01 & 30.73 & 9.47 \\
\hline 31 & 103.91 & -259.85 & -71.43 & 3.84 & 199.78 & 33.81 & 20.37 & 7.04 \\
\hline 32 & 103.91 & -259.85 & -71.43 & 3.84 & 396.06 & 230.10 & 138.64 & 16.44 \\
\hline 33 & 103.91 & -259.85 & -71.43 & 3.84 & 55.41 & -110.56 & -66.62 & 2.44 \\
\hline 34 & 103.91 & -259.85 & -71.43 & 3.84 & 197.20 & 31.24 & 18.82 & 5.55 \\
\hline 35 & 103.91 & -259.85 & -71.43 & 3.84 & 128.91 & -37.05 & -22.33 & 5.94 \\
\hline 36 & 444.28 & 80.52 & 22.14 & 15.16 & 280.91 & 114.94 & 69.25 & 9.72 \\
\hline 37 & 541.27 & 177.51 & 48.80 & 19.27 & 195.63 & 29.67 & 17.88 & 14.47 \\
\hline 38 & 695.72 & 331.96 & 91.26 & 38.11 & 434.41 & 268.44 & 161.74 & 25.38 \\
\hline 39 & 412.27 & 48.51 & 13.34 & 14.08 & 80.96 & -85.00 & -51.22 & 4.26 \\
\hline 40 & 682.87 & 319.12 & 87.73 & 22.71 & 187.16 & 21.20 & 12.77 & 5.11 \\
\hline 41 & 428.83 & 65.07 & 17.89 & 14.76 & 104.83 & -61.13 & -36.83 & 4.89 \\
\hline 42 & 563.52 & 199.77 & 54.92 & 19.15 & 148.71 & -17.26 & -10.40 & 7.86 \\
\hline 43 & 455.03 & 91.28 & 25.09 & 15.27 & 176.25 & 10.28 & 6.19 & 6.60 \\
\hline 44 & 548.09 & 184.34 & 50.68 & 19.05 & 117.77 & -48.19 & -29.04 & 5.34 \\
\hline 45 & 462.04 & 98.29 & 27.02 & 16.06 & 109.21 & -56.75 & -34.20 & 5.41 \\
\hline 46 & 588.57 & 224.82 & 61.80 & 21.40 & 85.01 & -80.96 & -48.78 & 2.66 \\
\hline 47 & 506.79 & 143.03 & 39.32 & 17.43 & 214.44 & 48.48 & 29.21 & 8.35 \\
\hline 48 & 545.01 & 181.26 & 49.83 & 19.08 & 67.78 & -98.19 & -59.16 & 3.06 \\
\hline 49 & 725.62 & 361.87 & 99.48 & 25.72 & 152.90 & -13.07 & -7.87 & 11.60 \\
\hline 50 & 506.68 & 142.92 & 39.29 & 18.56 & 274.50 & 108.53 & 65.39 & 9.01 \\
\hline
\end{tabular}


Table 4 (continued)

\begin{tabular}{llcccccrr}
\hline Sampling site & HPI PRM & Mean deviation & \% deviation & MI PRM & HPI POM & Mean deviation 2 & \% deviation 3 & MI POM \\
\hline 51 & 526.93 & 163.17 & 44.86 & 18.51 & 172.20 & 6.24 & 3.76 & 4.49 \\
52 & 527.80 & 164.04 & 45.10 & 17.97 & 122.94 & -43.03 & -25.93 \\
53 & 578.13 & 214.37 & 58.93 & 21.76 & 111.81 & -54.15 & -32.63 \\
54 & 535.03 & 171.27 & 47.08 & 20.69 & 99.21 & -66.76 & -40.22 & 5.39 \\
\hline
\end{tabular}

Table 5 Variables for calculating heavy metal pollution index for the mean concentration

\begin{tabular}{|c|c|c|c|c|c|c|c|c|c|}
\hline \multirow[t]{2}{*}{$\begin{array}{l}\text { Heavy metal } \\
\text { in Ppb }\end{array}$} & \multicolumn{2}{|c|}{$\begin{array}{l}\text { Mean concentration } \\
\left(M_{\mathrm{i}}\right)\end{array}$} & \multirow[t]{2}{*}{$\begin{array}{l}\text { Standard permis- } \\
\text { sible limit } S_{\mathrm{i}}\end{array}$} & \multirow[t]{2}{*}{$\begin{array}{l}\text { Highest desirable } \\
\text { value }\left(I_{\mathrm{i}}\right)\end{array}$} & \multirow[t]{2}{*}{ Unit weightage $W_{\mathrm{i}}$} & \multicolumn{2}{|c|}{ Sub-index $\left(Q_{\mathrm{i}}\right)$} & \multicolumn{2}{|l|}{$W_{\mathrm{i}} \times Q_{\mathrm{i}}$} \\
\hline & PRE & POM & & & & PRE & POM & PRE & POM \\
\hline $\mathrm{Fe}$ & 630 & 51 & 1000 & 100 & 0.001 & 58.89 & 49.56 & 0.0589 & 0.050 \\
\hline $\mathrm{Mn}$ & 478 & 10.8 & 300 & 100 & 0.0033 & 189 & 209 & 0.63 & 0.697 \\
\hline $\mathrm{Cu}$ & 142 & 24.4 & 1000 & 50 & 0.001 & 9.68 & 0.84 & 0.0097 & 0.001 \\
\hline $\mathrm{Ni}$ & 82 & 3.9 & 20 & & 0.05 & 410 & 175 & 20.5 & 8.750 \\
\hline $\mathrm{Pb}$ & 163 & 21 & 50 & & 0.02 & 326 & 50 & 6.52 & 1.000 \\
\hline $\mathrm{Zn}$ & 48 & 8.7 & 5000 & 200 & 0.0002 & 3.17 & 0.67 & 0.00063 & 0.000 \\
\hline $\mathrm{Cr}$ & 262 & 44.9 & 50 & & 0.02 & 524 & 124 & 10.48 & 2.480 \\
\hline
\end{tabular}

Pre-monsoon $\sum Q_{i}=1520.74 \sum W_{i} \times Q_{i}=38.19921$ HPI average $=399.8521$

Post-monsoon $\sum Q_{i}=607.380117=\sum W_{i} \times Q_{i} 12.975513$ HPI average $=135.8218$

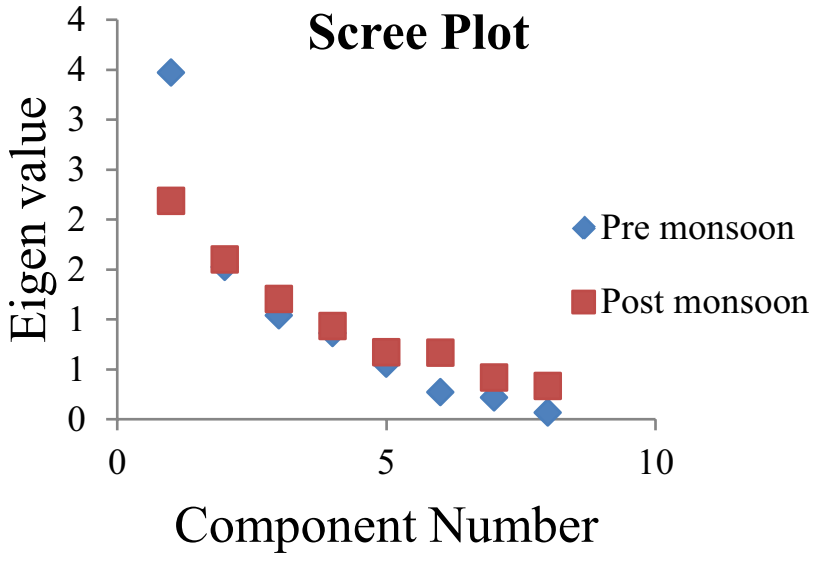

Fig. 10 Scree plot of the component in PCA for pre-monsoon and post-monsoon

Table 6 Classification of the groundwater on the basis of metal index
$\mathrm{MI}=\sum_{i=1}^{n} \frac{M_{i}}{S_{i}} \times 100$

MI is the metal index and $M_{i}$ is the concentration of individual metals that were present in the water and $S_{i}$ is the maximum concentration of the heavy metals that were allowed by WHO. The metal index was computed for all the sampling stations and is given in Table 4.

It can be seen from Tables 4 and 6 that there was no groundwater in the area, which was very pure in both the monsoon periods according to metal index. During pre-monsoon, there were no samples in the study area, which may be categorized as marginally affected with respect to heavy metal contamination. In the post-monsoon samples, due to dilution of groundwater, sample station 2 showed values that was marginally affected with respect to heavy metal contamination. Seven sites were found to be moderately affected

\begin{tabular}{llll}
\hline MI & Property of water & \multicolumn{2}{l}{ Groundwater sampling sites } \\
\cline { 3 - 4 } & & PRE & POM \\
\hline$<0.3$ & Very pure & \\
$0.3-1.0$ & Pure & & \\
$1.0-2.0$ & Slightly affected & & 1,7 \\
$2.0-4.0$ & Moderately affected & $1,3,31-35$ & $2,13,16,29,33,46,48$, \\
$4.0-6.0$ & Strongly affected & $2,4-7$ & $6,9,11,12,17,34,35,39-41,44,45,51,54$ \\
$>6.0$ & Serious affected & $8-30,36-54$ & $3-5,8,10,14,15,18-28,30-32,36-38$, \\
& & & $42,43,47,49,50,52,53$ \\
\hline
\end{tabular}


by heavy metal contamination in the pre-monsoon and postmonsoon seasons. Five samples were significantly affected with heavy metal contamination in the pre-monsoon, and alarmingly 42 sampling stations were found to be severely affected with heavy metal contamination during pre-monsoon period. In the post-monsoon season, 14 stations were significantly affected and 31 samples were severely affected with heavy metal contamination. These results show that immediate action should be taken to reduce the concentration of the heavy metal in the groundwater. The sources of the heavy metal in the groundwater were mainly due to the anthropogenic activities, and mainly industrial and e-waste contribute more towards the heavy metal concentration.

\section{Correlation and PCA}

Correlation of the heavy metal was studied to understand the relationship between various metals (Muhammad et al. 2010; Belkhiri and Narany 2015; Jacintha et al. 2016; Giridharan et al. 2009; Venugopal et al. 2008) and is presented in Tables 7 and 8. $\mathrm{pH}$ was also included for the analysis of correlation and PCA since $\mathrm{pH}$ was one of the main reasons for the dissolution of metal from the minerals. But from Tables 7 and 8 , it can be seen that $\mathrm{pH}$ has no correlation with any of the heavy metals, the $r$ value for both the seasons was found to be less than 0.4. In the pre-monsoon, it was found that $\mathrm{Fe}, \mathrm{Mn}$ and $\mathrm{Zn}$ do not show correlation with other metals, while $\mathrm{Cu}$ showed the highest correlation with chromium among the heavy metals with $r$ value nearly 0.90 . Copper also showed a good correlation with $\mathrm{Pb}$ with $r$ value of 0.76 ; it also showed a lesser correlation with $\mathrm{Ni}$. Nickel also showed correlation with lead with $r$ value 0.735 . Lead was found to correlate with $\mathrm{Cr}$ with an $r$ value of nearly 0.75 . In the post-monsoon, it was found that there was no significant correlation between any metals and $r$ value was found to be less than 0.60. So it can be concluded that the source of heavy metals in the pre-monsoon was quite different and no common source was available for all heavy metals and the source of the heavy metals was not clearly geogenic. Since the area was industrialized with different kinds of industries, mainly small-scale industries, tyre industry and heavy vehicle manufacturing industry, the industrial effluent would have greatly influenced the pollution in the area.

Principal component analysis of the heavy metals was carried out with IBM SPSS statistics 25. Varimax rotation was used to determine the factors which control the heavy metal pollution in the area. Kaiser-Meyer-Olkin (KMO) for the pre-monsoon was 0.658 and for post-monsoon it was 0.556 (Tables 9 and 11); it can be seen that for both the seasons, the sampling adequacy was greater than 0.5 and it was adequate and no remedial action was required. For both the seasons, Bartlett's test of sphericity gave a highly significant value with $P<0.001$, which indicates that the correlation matrix has significant relationships between the variables and it was not an identity matrix. The results of the PCA are given in Tables 9, 10, 11, 12 for the pre-monsoon
Table 7 Correlation of various heavy metals in the groundwater during pre-monsoon season

\begin{tabular}{|c|c|c|c|c|c|c|c|c|}
\hline & $\mathrm{pH}$ & $\mathrm{Fe}$ & $\mathrm{Mn}$ & $\mathrm{Cu}$ & $\mathrm{Ni}$ & $\mathrm{Pb}$ & $\mathrm{Zn}$ & $\mathrm{Cr}$ \\
\hline $\mathrm{pH}$ & 1.000 & -0.116 & -0.287 & 0.026 & -0.081 & 0.023 & -0.060 & 0.236 \\
\hline $\mathrm{Fe}$ & & 1.000 & 0.431 & 0.215 & 0.220 & 0.221 & 0.163 & 0.248 \\
\hline $\mathrm{Mn}$ & & & 1.000 & 0.068 & 0.424 & 0.211 & -0.015 & 0.140 \\
\hline $\mathrm{Cu}$ & & & & 1.000 & 0.656 & 0.763 & 0.165 & 0.892 \\
\hline $\mathrm{Ni}$ & & & & & 1.000 & 0.735 & 0.062 & 0.704 \\
\hline $\mathrm{Pb}$ & & & & & & 1.000 & 0.092 & 0.747 \\
\hline $\mathrm{Zn}$ & & & & & & & 1.000 & 0.197 \\
\hline $\mathrm{Cr}$ & & & & & & & & 1.000 \\
\hline
\end{tabular}

Table 8 Correlation of various heavy metals in the groundwater during post-monsoon season

\begin{tabular}{|c|c|c|c|c|c|c|c|c|}
\hline & $\mathrm{pH}$ & $\mathrm{Fe}$ & $\mathrm{Mn}$ & $\mathrm{Cu}$ & $\mathrm{Ni}$ & $\mathrm{Pb}$ & $\mathrm{Zn}$ & $\mathrm{Cr}$ \\
\hline $\mathrm{pH}$ & 1.000 & 0.044 & -0.076 & -0.185 & 0.144 & -0.207 & -0.229 & -0.036 \\
\hline $\mathrm{Fe}$ & & 1.000 & 0.322 & 0.235 & 0.178 & -0.186 & 0.145 & 0.060 \\
\hline $\mathrm{Mn}$ & & & 1.000 & 0.057 & 0.424 & -0.050 & 0.233 & 0.560 \\
\hline $\mathrm{Cu}$ & & & & 1.000 & -0.047 & 0.149 & 0.449 & -0.044 \\
\hline $\mathrm{Ni}$ & & & & & 1.000 & 0.038 & 0.288 & 0.259 \\
\hline $\mathrm{Pb}$ & & & & & & 1.000 & 0.179 & 0.028 \\
\hline $\mathrm{Zn}$ & & & & & & & 1.000 & 0.174 \\
\hline $\mathrm{Cr}$ & & & & & & & & 1.000 \\
\hline
\end{tabular}


Table 9 Results of the principal component analysis for the groundwater samples during pre-monsoon season, total variance explained

\begin{tabular}{|c|c|c|c|c|c|c|c|c|c|}
\hline \multirow[t]{2}{*}{ Component } & \multicolumn{3}{|c|}{ Initial eigen values } & \multicolumn{3}{|c|}{ Extraction sums of squared loadings } & \multicolumn{3}{|c|}{ Rotation sums of squared loadings } \\
\hline & Total & $\%$ of variance & Cumulative $\%$ & Total & $\%$ of variance & Cumulative $\%$ & Total & $\%$ of variance & Cumulative\% \\
\hline 1 & 3.471 & 43.386 & 43.386 & 3.471 & 43.386 & 43.386 & 3.323 & 41.539 & 41.539 \\
\hline 2 & 1.523 & 19.042 & 62.428 & 1.523 & 19.042 & 62.428 & 1.626 & 20.321 & 61.860 \\
\hline 3 & 1.037 & 12.968 & 75.396 & 1.037 & 12.968 & 75.396 & 1.083 & 13.536 & 75.396 \\
\hline 4 & 0.859 & 10.739 & 86.135 & & & & & & \\
\hline 5 & 0.556 & 6.951 & 93.086 & & & & & & \\
\hline 6 & 0.269 & 3.363 & 96.449 & & & & & & \\
\hline 7 & 0.219 & 2.740 & 99.189 & & & & & & \\
\hline 8 & 0.065 & 0.811 & 100.000 & & & & & & \\
\hline \multicolumn{10}{|c|}{$\begin{array}{l}\text { KMO and Bartlett's test } \\
\text { Kaiser-Meyer-Olkin measure of sampling adequacy } 0.658\end{array}$} \\
\hline \multirow[t]{3}{*}{$\begin{array}{l}\text { Bartlett's test } \\
\text { of sphericity }\end{array}$} & $\begin{array}{c}\text { Approx. } \\
\text { Chi- } \\
\text { square }\end{array}$ & 227.805 & & & & & & & \\
\hline & $d f$ & 28 & & & & & & & \\
\hline & Sig. & 0.000 & & & & & & & \\
\hline
\end{tabular}

Extraction method: Principal component analysis

Table 10 Factor loading of the principal component extracted for the pre-monsoon season

\begin{tabular}{lllllllll}
\hline & \multicolumn{2}{l}{ Original component } & & & \multicolumn{2}{l}{ Rotated component } & \multirow{2}{*}{ Communalities } \\
\cline { 2 - 3 } & 1 & 2 & 3 & & 1 & 2 & 3 & \\
\hline $\mathrm{pH}$ & 0.010 & -0.701 & -0.019 & & 0.176 & -0.678 & -0.027 & 0.492 \\
$\mathrm{Fe}$ & 0.402 & 0.543 & 0.253 & & 0.227 & 0.609 & 0.312 & 0.520 \\
$\mathrm{Mn}$ & 0.366 & 0.755 & -0.205 & & 0.203 & 0.828 & -0.143 & 0.747 \\
$\mathrm{Cu}$ & 0.888 & -0.241 & 0.031 & & 0.908 & -0.032 & 0.149 & 0.847 \\
$\mathrm{Ni}$ & 0.860 & 0.099 & -0.215 & & 0.834 & 0.304 & -0.094 & 0.796 \\
$\mathrm{~Pb}$ & 0.880 & -0.117 & -0.118 & 0.891 & 0.095 & 0.002 & 0.802 \\
$\mathrm{Zn}$ & 0.210 & 0.034 & 0.932 & & 0.074 & 0.040 & 0.952 & 0.913 \\
$\mathrm{Cr}$ & 0.910 & -0.289 & 0.043 & & 0.939 & -0.073 & 0.163 & 0.914 \\
\hline
\end{tabular}

Extraction Method: Principal component analysis. Three components extracted. and post-monsoon, respectively. The scree plot for both the monsoons is shown in Fig. 10.

The results of the PCA and the extracted components show that three components have eigen values more than 1 in both the monsoons. In the PCA analysis, eigen value was considered to indicate the significance of the components, and normally a component is taken as significant when the eigen value is greater than 1 . Eigen values less than 1 were considered not significant as these values normally do not contribute much towards the principal component analysis. In the pre-monsoon, from Table 9, it can be inferred that the first three components contribute nearly $75.4 \%$ of the total variance, while in the postmonsoon, from Table 11, it can be seen that the first three components give only $62.2 \%$ of the total variance. The post-monsoon results show the samples were less homogeneous than the pre-monsoon and the contributing factor towards the pollution was numerous. The factor loading of various heavy metals is given in Tables 10 and 12 for the pre-monsoon and post-monsoon, respectively. When the factor loading for a particular metal was greater than 0.75 , the contribution of the metal towards the component was considered to be strong, and when the factor loading was between 0.75 and 0.5 , it was considered as moderate and when the same was between 0.5 and 0.3 , it was considered to be contributed very weakly. From Table 10, it can be inferred that in the pre-monsoon, Factor 1 (PC 1) has a strong contribution from $\mathrm{Cu}, \mathrm{Ni}, \mathrm{Pb}$ and $\mathrm{Cr}$. These metals as discussed earlier had strong correlation between them. So it can be considered that these metals have a common origin in the pre-monsoon season and the origin was considered to be mainly due to industrial pollution and dumping of waste near the lake area. Mn seems to 
Table 11 Results of the principal component analysis for the groundwater samples during post-monsoon season, total variance explained

\begin{tabular}{|c|c|c|c|c|c|c|c|c|c|}
\hline \multirow[t]{2}{*}{ Component } & \multicolumn{3}{|c|}{ Initial eigen values } & \multicolumn{3}{|c|}{ Extraction sums of squared loadings } & \multicolumn{3}{|c|}{ Rotation sums of squared loadings } \\
\hline & Total & $\%$ of variance & Cumulative $\%$ & Total & $\%$ of variance & Cumulative $\%$ & Total & $\%$ of variance & Cumulative $\%$ \\
\hline 1 & 2.184 & 27.300 & 27.300 & 2.184 & 27.300 & 27.300 & 1.961 & 24.514 & 24.514 \\
\hline 2 & 1.597 & 19.962 & 47.263 & 1.597 & 19.962 & 47.263 & 1.635 & 20.440 & 44.954 \\
\hline 3 & 1.202 & 15.023 & 62.285 & 1.202 & 15.023 & 62.285 & 1.386 & 17.331 & 62.285 \\
\hline 4 & 0.932 & 11.648 & 73.933 & & & & & & \\
\hline 5 & 0.671 & 8.393 & 82.326 & & & & & & \\
\hline 6 & 0.666 & 8.324 & 90.649 & & & & & & \\
\hline 7 & 0.416 & 5.200 & 95.850 & & & & & & \\
\hline 8 & 0.332 & 4.150 & 100.000 & & & & & & \\
\hline \multicolumn{10}{|c|}{ KMO and Bartlett's test } \\
\hline \multicolumn{10}{|c|}{ Kaiser-Meyer-Olkin measure of sampling adequacy 0.556} \\
\hline \multirow[t]{3}{*}{$\begin{array}{l}\text { Bartlett's test } \\
\text { of sphericity }\end{array}$} & $\begin{array}{l}\text { Approx. } \\
\text { Chi- } \\
\text { square }\end{array}$ & 70.390 & & & & & & & \\
\hline & $d f$ & 28 & & & & & & & \\
\hline & Sig. & 0.000 & & & & & & & \\
\hline
\end{tabular}

Extraction method: Principal component analysis

Table 12 Factor loading of the principal component extracted for the post-monsoon season

\begin{tabular}{|c|c|c|c|c|c|c|c|}
\hline & \multicolumn{3}{|c|}{ Original component } & \multicolumn{3}{|c|}{ Rotated component } & \multirow[t]{2}{*}{ Communalities } \\
\hline & 1 & 2 & 3 & 1 & 2 & 3 & \\
\hline $\mathrm{pH}$ & -0.177 & 0.599 & 0.228 & 0.030 & -0.319 & 0.582 & 0.442 \\
\hline $\mathrm{Fe}$ & 0.467 & 0.143 & 0.680 & 0.218 & 0.570 & 0.573 & 0.701 \\
\hline Mn & 0.789 & 0.313 & -0.114 & 0.833 & 0.178 & 0.092 & 0.734 \\
\hline $\mathrm{Cu}$ & 0.367 & -0.637 & 0.443 & -0.118 & 0.841 & -0.126 & 0.737 \\
\hline $\mathrm{Ni}$ & 0.611 & 0.326 & -0.127 & 0.694 & 0.065 & 0.100 & 0.496 \\
\hline $\mathrm{Pb}$ & 0.101 & -0.545 & -0.524 & 0.032 & 0.072 & -0.759 & 0.582 \\
\hline $\mathrm{Zn}$ & 0.640 & -0.472 & 0.071 & 0.309 & 0.673 & -0.299 & 0.638 \\
\hline $\mathrm{Cr}$ & 0.619 & 0.297 & -0.427 & 0.791 & -0.090 & -0.140 & 0.654 \\
\hline
\end{tabular}

Extraction method: Principal component analysis. Three components extracted contribute strongly towards the factor 2 (PC 2), and $\mathrm{Fe}$ seems to contribute moderately towards it. So, the origin of $\mathrm{Mn}$ and $\mathrm{Fe}$ seems to be more from domestic waste in the pre-monsoon season. Factor 2 seems to have origin from the domestic waste. $\mathrm{Zn}$ was the only variable which contributes towards the factor 3 (PC 3) strongly in the pre-monsoon. In the post-monsoon (Table 12), the origin of the metal was difficult to follow as the contributing variable towards the factor was not very strong. Mn seems to contribute strongly towards the factor 1 followed by $\mathrm{Ni}$, $\mathrm{Zn}$ and $\mathrm{Cr}$, which contribute moderately, and a weak contribution was seen to be from $\mathrm{Fe}, \mathrm{Cu}$. $\mathrm{pH}$ seems to contribute moderately towards the factor 2 in the post-monsoon followed by weak contribution from $\mathrm{Mn}, \mathrm{Cu}$ and $\mathrm{Cr}$. In the post-monsoon, there seems to be no distinct source as domestic or industrial. Factor 3 seems to have moderate contribution from $\mathrm{Fe}$, and $\mathrm{Cu}$ shows weak contribution.

\section{Conclusion}

HPI and MI indicate that the groundwater in the northern Chennai was highly affected with heavy metal contamination, and there should be immediate measure to be taken to control the pollution. The main source of the pollution was found to be domestic and industrial waste, which was dumped near the surface water. ANOVA and $t$-test indicate that there was a common source of origin of the heavy metals in the groundwater and as indicated the main source is mainly industrial and domestic pollutant. Southern part of the study area was seriously affected than the other parts. Results of correlation and principal component analysis 
indicate that certain heavy metals, viz., $\mathrm{Cu}, \mathrm{Ni}, \mathrm{Pb}$ and $\mathrm{Cr}$, show common origin, especially from the industrial and domestic wastes during pre-monsoon in the study area. The study assumes much significances since it was a comprehensive study of the heavy metal pollution in the area and gives an idea of the origin of these metals. This study can be used by government agencies and other agencies to develop a comprehensive plan to reduce the heavy metal content in this area.

Funding The authors received no specific funding for this work.

\section{Compliance with ethical standards}

Conflict of interest S. R. Mahapatra, T. Venugopal and other author state that there are no conflictsof interest

Open Access This article is licensed under a Creative Commons Attribution 4.0 International License, which permits use, sharing, adaptation, distribution and reproduction in any medium or format, as long as you give appropriate credit to the original author(s) and the source, provide a link to the Creative Commons licence, and indicate if changes were made. The images or other third party material in this article are included in the article's Creative Commons licence, unless indicated otherwise in a credit line to the material. If material is not included in the article's Creative Commons licence and your intended use is not permitted by statutory regulation or exceeds the permitted use, you will need to obtain permission directly from the copyright holder. To view a copy of this licence, visit http://creativecommons.org/licenses/by/4.0/.

\section{References}

Abou Zakhem B, Hafez R (2014) Heavy metal pollution index for groundwater quality assessment in Damascus Oasis, Syria. Environ Earth Sci 73(10):6591-6600. https://doi.org/10.1007/s1266 5-014-3882-5

Balakrishnan A (2016) Evaluation of heavy metal pollution index (HPI) of ground water in and around the coastal area of Gulf of Mannar Biosphere and Palk Strait. J Adv Chem Sci 2(3):331-333

Belkhiri L, Narany TS (2015) Using multivariate statistical analysis, geostatistical techniques and structural equation modeling to identify spatial variability of groundwater quality. Water Resour Manag 29(6):2073-2089. https://doi.org/10.1007/s1126 9-015-0929-7

Bhardwaj R, Gupta A, Garg JK (2017) Evaluation of heavy metal contamination using environmetrics and indexing approach for River Yamuna, Delhi. Stretch India Water Sci 1(1):52-66

Chaturvedi A, Bhattacharjee S, Singh AK, Kumar V (2018) A new approach for indexing groundwater heavy metal pollution. Ecol Indic 87:323-331. https://doi.org/10.1016/j.ecolind.2017.12.052

Das Kangabam R, Bhoominathan SD, Kanagaraj S, Govindaraju M (2017) Development of a water quality index (WQI) for the Loktak Lake in India. Appl Water Sci 7(6):2907-2918. https://doi. org/10.1007/s13201-017-0579-4

Gautam SK, Evangelos T, Singh SK, Tripathi JK, Singh AK (2018) Environmental monitoring of water resources with the use of PoS index: a case study from Subarnarekha River basin, India. Environ Earth Sci. https://doi.org/10.1007/s12665-018-7245-5
Giridharan L, Venugopal T, Jayaprakash M (2009) Assessment of water quality using chemometric tools: a case study of river Cooum. South India Arch Environ Contam Toxicol 56(4):654-669. https ://doi.org/10.1007/s00244-009-9310-2

Govil PK, Krishna AK (2018) Soil and water contamination by potentially hazardous elements: a case history from India. Environ Geochem. Site characterization, data analysis and case histories. 1st edition, pp 567-597 https://doi.org/10.1016/B978-0-444-63763 $-5.00023-9$

Jacintha TGA, Rawat KS, Mishra A, Singh SK (2016) Hydrogeochemical characterization of groundwater of peninsular Indian region using multivariate statistical techniques. Appl Water Sci 7(6):3001-3013. https://doi.org/10.1007/s13201-015-0313-z

Krishna kumar S, Logeshkumaran A, Magesh NS, Godson PS, Chandrasekar N (2014) Hydro-geochemistry and application of water quality index (WQI) for groundwater quality assessment, Anna Nagar, part of Chennai City, Tamil Nadu, India. App Water Sci. 5(4):335-343. https://doi.org/10.1007/s13201-014-0196-4

Mohan SV, Nithila P, Reddy SJ (2008) Estimation of heavy metals in drinking water and development of heavy metal pollution index. J Environ Sci Heal A 31(2):283-289. https://doi.org/10.1080/10934 529609376357

Mor S, Negi P, Khaiwal R (2018) Assessment of groundwater pollution by landfills in India using leachate pollution index and estimation of error. Environ nanotechnol monit manage 10:467-476

Muhammad S, Shah MT, Khan S (2011) Health risk assessment of heavy metals and their source apportionment in drinking water of Kohistan region, northern Pakistan. Microchem J 98(2):334-343. https://doi.org/10.1016/j.microc.2011.03.003

Muhammad S, Tahir Shah M, Khan S (2010) Arsenic health risk assessment in drinking water and source apportionment using multivariate statistical techniques in Kohistan region, northern Pakistan. Food Chem Toxicol 48(10):2855-2864. https://doi. org/10.1016/j.fct.2010.07.018

Pant RR, Zhang F, Rehman FU, Wang G, Ye M, Zeng C, Tang H (2018) Spatiotemporal variations of hydrogeochemistry and its controlling factors in the Gandaki River Basin, Central Himalaya Nepal. Sci Total Environ 622-623:770-782. https://doi. org/10.1016/j.scitotenv.2017.12.063

Prasad B, Sangita K (2008) Heavy metal pollution index of ground water of an abandoned open cast mine filled with fly ash: a case study. Mine Water Environ 27(4):265-267. https://doi. org/10.1007/s10230-008-0050-8

Prasad B, Jaiprakas KC (1999) Evaluation of heavy metals in ground water near mining area and development of heavy metal pollution index. J Environ Sci Health A34(1):91-102

Prasad B, Kumari P, Bano S, Kumari S (2013) Ground water quality evaluation near mining area and development of heavy metal pollution index. Appl Water Sci 4(1):11-17. https://doi.org/10.1007/ s13201-013-0126-x

Rahfeld A, Wiehl N, Dressler S, Möckel R, Gutzmer J (2018) Major and trace element geochemistry of the European Kupferschieferan evaluation of analytical techniques. Geochem Explor Environ Anal Geochem. https://doi.org/10.1144/geochem2017-033

Rakotondrabe F, Ngoupayou JRN, Mfonka Z, Rasolomanana EH, Nyangono Abolo AJ, Asone BL, Ako Ako A, Rakotondrabe MH (2017) Assessment of surface water quality of Betare-Oya gold mining area (East-Cameroon). J Water Res Prot 09(08):960-984. https://doi.org/10.4236/jwarp.2017.98064

Ravindra K, Mor S (2019) Distribution and health risk assessment of arsenic and selected heavy metals in Groundwater of Chandigarh, India. Environ Pollut 250:820-830

Ravindra K, Thind PS, Mor S, Singh T, Mor S (2019) Evaluation of groundwater contamination in Chandigarh: source identification and health risk assessment. Environ Pollut 255:113062 
Sadat-Noori SM, Ebrahimi K, Liaghat AM (2013) Groundwater quality assessment using the Water Quality Index and GIS in SavehNobaran aquifer. Iran Environ Earth Sci 71(9):3827-3843. https ://doi.org/10.1007/s12665-013-2770-8

Saleem M, Hussain A, Mahmood G, Dubey S (2016) Analysis of groundwater quality using water quality index: A case study of greater Noida (Region), Uttar Pradesh (UP), India. Cogent Eng. https://doi.org/10.1080/23311916.2016.1237927

Sharma DA, Rishi MS, Keesari T (2017) Evaluation of groundwater quality and suitability for irrigation and drinking purposes in southwest Punjab, India using hydrochemical approach. Appl Water Sci 7(6):3137-3150

Singh G, Kamal RK (2016) Heavy metal contamination and its indexing approach for groundwater of Goa mining region, India. Appl Water Sci 7(3):1479-1485. https://doi.org/10.1007/s1320 1-016-0430-3

Tamasi G, Cini R (2004) Heavy metals in drinking waters from Mount Amiata (Tuscany, Italy). Possible risks from arsenic for public health in the Province of Siena. Sci Total Environ 327(1-3):4151. https://doi.org/10.1016/j.scitotenv.2003.10.011
Tiwari AK, De Maio M, Singh PK, Mahato MK (2015) Evaluation of surface water quality by using GIS and a heavy metal pollution index (HPI) model in a coal mining area. India Bull Environ Contam Toxicol 95(3):304-310. https://doi.org/10.1007/s0012 8-015-1558-9

Tiwari AK, Singh PK, Singh AK, De Maio M (2016) Estimation of heavy metal contamination in groundwater and development of a heavy metal pollution index by using GIS technique. Bull Environ Contam Toxicol 96(4):508-515. https://doi.org/10.1007/s0012 8-016-1750-6

Venugopal T, Giridharan L, Jayaprakash M (2008) Groundwater quality assessment using chemometric analysis in the Adyar River. South India Arch Environ Contam Toxicol 55(2):180-190. https ://doi.org/10.1007/s00244-007-9117-y

Publisher's Note Springer Nature remains neutral with regard to jurisdictional claims in published maps and institutional affiliations. 